\title{
INTERPRETING SEGTION 4(f)(2) OF THE ADEA: DOES ANYONE HAVE A "PLAN"?
}

\section{BrUCE E. REINHART $\dagger$}

In 1967, Congress enacted the Age Discrimination in Employment Act ("ADEA" or "Act") 1 to promote employment of older workers" and eliminate discrimination on the basis of age. ${ }^{3}$ The drafters of the Act recognized that some employee benefits are more expensive to provide to older workers and feared that requiring that all employees receive the same benefits would dissuade employers from hiring older workers. ${ }^{4}$ To remedy this perceived problem, Congress included section $4(f)(2)$, making lawful any action taken in "observ[ance] of . . . any bona fide employee benefit plan, such as a retirement, pension, or insurance plan, which is not a subterfuge to evade the purposes of [the ADEA].".

Although the ADEA's legislative history makes clear that section $4(f)(2)$ had the narrow purpose of permitting cost-justified reductions in benefits for older workers, it provides no guidance in interpreting the key terms of section $4(f)(2)$. Instead, the interpretation of those terms has been left to the judicial process. The courts, however, have lost sight of the section's narrow scope and needlessly confuse its interpretation. The incorrect interpretation of section 4(f)(2) creates problems for both actual and potential litigants, distorts Congress's initial intentions

† B.S.E. 1984, Princeton University; J.D. Candidate 1987, University of Pennsylvania.

1 Pub. L. No. 90-202, 81 Stat. 602 (1967) (codified as amended at 29 U.S.C. $\S \S 621-634$ (1982 \& Supp. III 1985 \& West Supp. 1986)), as last amended by Act of Apr. 7, 1986, Pub. L. No. 99-272, § 9201(b), 1986 U.S. Code Cong. \& ADMIN. News (100 Stat.) 82, 171; Act of Oct. 31, 1986, Pub. L. No. 99-592, 1986 U.S. Cone Cong. \& ADMIN. News (100 Stat.) 3342.

2 Employees within the protected age group of the ADEA are referred to as "older workers."

3 See Pub. L. No. 90-202, § 2(b), 81 Stat. 602, 602 (1967) (codified as amended at 29 U.S.C. $\S 621$ (b) (1982)). The Act originally protected workers between ages 40 and 65 . The 1978 amendments extended coverage to workers between 40 and 70 . See Pub. L. No. 95-256, § 3(a), 92 Stat. 189, 190 (1978) (codified as amended at 29 U.S.C. § 631(a) (1982)). A 1986 amendment removed the upper age limit and extended ADEA protection to all workers over 40. See Act of Oct. 31, 1986, Pub. L. No. 99-592, § 2, 1986 U.S. Code Cong. \& Admin. News (100 Stat.) 3342, 3342.

See infra text accompanying notes 28-37.

- 29 U.S.C. § 623(f)(2) (1982). As part of the 1978 amendments, Congress outlawed involuntary retirement of older workers. See Pub. L. No. 95-256, § 2(a), 92 Stat. 189, 189 (1978). 
in exempting certain benefit plans from ADEA coverage, and threatens the traditional deference to collective bargaining agreements ${ }^{6}$ that has been afforded by the courts.

The recent appellate decisions in EEOC $v$. Westinghouse Electric Corp. ${ }^{8}$ ('Westinghouse I") and EEOC v. Borden's, Inc. ${ }^{9}$ announced a test for whether an employee benefit plan is an "employee benefit plan, such as a retirement, pension, or insurance plan" within the meaning of section $4(\mathrm{f})(2)$. This test has no basis in the legislative history, is inconsistent with the language of the statute, and is needlessly restrictive. Other courts of appeals have refused to adopt it. ${ }^{10}$ A clearer statutory test should minimize potential litigation and should result in the application of the ADEA in a manner that comports more accurately with the statute's legislative history. If the law is unambiguous and easily applied, potential litigants can better assess their claims and may settle disputes without resorting to legal action. This Comment criticizes the Westinghouse $I$ test and proposes an alternative that would avoid its problems.

Westinghouse I and Borden's arose from the denial of benefits at the time of plant closings. With plant closings becoming more prevalent, additional ADEA claims are likely. Such a claim can delay significantly the final resolution of the plant closing. For example, Westinghouse Electric Corporation closed its Belleville, New Jersey, plant in $1977,{ }^{11}$ but the age discrimination case was not resolved until 1984. No party to a plant closing gains from such a delay. The older worker, after losing a job due to the plant closing, may need the contested benefits to minimize the disruption of her life. Even ultimate victory in an age discrimination suit does not avoid this initial disruption. Similarly, for unions, the uncertainty of litigation in this area creates doubts as to

6 This Comment considers only employment relationships involving collective bargaining. It should be noted, however, that many employers also provide employee benefits in the absence of collective bargaining.

7 See The Steelworkers Trilogy Cases (United Steelworkers of America v. American Mfg. Co., 363 U.S. 564, 568-69 (1960); United Steelworkers of America v. Warrior \& Gulf Navigation Co., 363 U.S. 574, 578-79 (1960); United Steelworkers of America v. Enterprise Wheel \& Car Corp., 363 U.S. 593, 596 (1960)).

8 725 F.2d 211 (3d Gir. 1983), cert. denied, 469 U.S. 820 (1984). This case is designated Westinghouse $I$ to distinguish it from EEOC v. Westinghouse Elec. Corp., 632 F. Supp. 343 (E.D. Pa. 1986) ("Westinghouse II"). Westinghouse II also involves purported age discrimination under the company's layoff income and benefit ("LIB") plan.

724 F.2d 1390 (9th Cir. 1984).

10 See Cipriano v. Board of Educ., 785 F.2d 51 (2d Cir. 1986); Britt v. E.I. du Pont de Nemours \& Co., 768 F.2d 593 (4th Gir. 1985); Patterson v. Independent School Dist., 742 F.2d 465 (8th Cir. 1984); Parker v. Federal Nat'l Mortgage Ass'n, 741 F.2d 975 (7th Gir. 1984).

12 See 725 F.2d at 214. 
whether their negotiated collective bargaining agreement will be given full effect. Finally, the employer closing a plant prefers not to have lingering problems-especially litigation. Often, the reason for the plant closing is an unfavorable financial situation, and a financially troubled employer may not be able to afford the costs of lengthy litigation. Therefore, all concerned parties would benefit from a clear interpretation of the ADEA.

The Westinghouse I decision invalidated a term of the collective bargaining agreement that had existed for over a decade. This result is extreme and has severe consequences. A long-existing term in a collective agreement creates expectations on the part of both the employer and the workers. In the case of an employee benefit, the employer must anticipate the cost of the benefit in her financial planning. Similarly, the employee knows the amount of benefit to be received and can plan her finances accordingly. To invalidate a provision that limits the availability of a benefit creates a windfall for the employee and a large, unexpected expense for the employer. It also fails to recognize that collective bargaining involves trade-offs between different kinds of compensation and benefits. ${ }^{12}$ In addition, the invalidation of a collectively bargained provision by operation of law (i.e., the ADEA) distorts the parties' agreement and circumvents the bargaining process: a party to the agreement may agree to an unfavorable provision as a quid pro quo for a favorable one and then, many years later, seek to use the ADEA to abrogate the unfavorable provision. ${ }^{13}$

Part I of this Comment explores the structure of the ADEA and identifies two parameters with which any interpretation of the terms of section 4(f)(2) must be consistent: (1) the ADEA prohibits only agebased discrimination, and (2) section $4(f)(2)$ was intended by Congress only to allow reduced benefits for older workers where the cost of the benefit depends on the age of the employee. Part II focuses on interpreting the pertinent terms of section 4(f)(2). It first examines the legislative history for any interpretive guidance, then looks to the administrative regulations and the case law. The case law analysis traces the two ways in which employers claim their plans are "employee benefit

12 See infra note 158 and accompanying text.

13 A related issue that is beyond the scope of this Comment concerns steps an employer can, and should, take if $\S 4(f)(2)$ threatens to invalidate an existing collectively bargained severance agreement. Although renegotiation seems to be the most appropriate avenue, the realities of the situation may make renegotiation infeasible in the plant closing situation. The union may be uncooperative both because it is angered by the plant closing and because it could gain a substantial windfall if the severance pay plan is invalidated by operation of law and a court orders severance benefits for all employees. 
plans, such as a retirement, pension, or insurance plans." The first claim is that the plan independently falls within the statutory phrase. The Westinghouse $I$ test applies to this kind of claim. The second possible claim is that the plan is part of a larger, integrated benefit structure that, in its entirety, satisfies the statute. ${ }^{14}$ This part also examines several alternative interpretations of the terms of section $4(f)(2)$ that satisfy the requirement that the section only allow reduced benefits where the cost of the benefit is related to the age of the employee.

Part III demonstrates the inconsistencies of the Westinghouse I test and proposes an alternative that would avoid these problems. The proposed test combines the definition of "employee benefit plan" from the Employee Retirement Income Security Act ("ERISA")15 with the definition of "subterfuge to evade the purposes of [the ADEA]" from the ADEA regulations. Part IV briefly returns to the issue of integrated benefit plans and proposes criteria for evaluating whether a plan is part of an integrated scheme.

\section{THE SCOPE OF THE ADEA}

Section four of the ADEA contains the Act's prohibition against age discrimination. ${ }^{16}$ Section $4(a)$ describes those employment practices that are unlawful ${ }^{17}$ whereas section $4(f)$ specifically designates several practices as lawful: ${ }^{18}$

(a) It shall be unlawful for an employer-

(1) to fail or refuse to hire or to discharge any individual with respect to his compensation, terms, conditions, or privileges of employment, because of such individual's age;

(2) to limit, segregate, or classify his employees in any way which would deprive or tend to deprive any individual of employment opportunities or otherwise adversely affect his status as an employee, because of such

14 See EEOC v. Firestone Tire \& Rubber Co., 650 F. Supp. 1561 (W.D. Tenn. 1987); Brief for Appellant at 19-22, EEOC v. Westinghouse Elec. Corp. 632 F. Supp. 343 (E.D. Pa. 1986) 86-1226.

1829 U.S.C. $\$ 1002(1)$-(3) (1982 \& Supp. III 1985).

16 See 29 U.S.C. \& 623 (1982 \& Supp. III 1985 \& West Supp. 1986), as amended by Act of Apr. 7, 1986, Pub. L. No. 99-272, § 9201(b), 1986 U.S. CoDE Cong. \& Admm. News (100 Stat.) 82, 171; Act of Oct. 31, 1986, Pub. L. No. 99-592, 1986 U.S. Code Cong. \& Admin. News (100 Stat.) 3342.

${ }_{17}$ See 29 U.S.C. $\S 623(a)(1982)$. The language of $\S 4(a)$-(c) was taken from Title VII of the Civil Rights Act. Compare 29 U.S.C. § 623(a)-(c) (1982) with 42 U.S.C. $\S 2000 \mathrm{e}-2$ (a)-(c) (1982).

${ }^{18}$ See 29 U.S.C. \& 623(f) (1982 \& Supp. III 1985). 
individual's age; or

3) to reduce the wage rate of any employee in order to comply with this chapter.

(f) It shall not be unlawful for an employer, employment agency, or labor organization-

(1) to take any action otherwise prohibited under subsections (a), (b), (c), or (e) of this section where age is a bona fide occupational qualification reasonably necessary to the normal operation of the particular business, or where the differentiation is based on reasonable factors other than age, or where such practices involve an employee in a workplace in a foreign country, and compliance with such section would cause such employer, or a corporation controlled by such employer, to violate the laws of the country in which such workplace is located;

(2) to observe the terms of a bona fide seniority system or any bona fide employee benefit plan such as a retirement, pension, or insurance plan, which is not a subterfuge to evade the purposes of this chapter, except that no such employee benefit plan shall excuse the failure to hire any individual, and no such seniority system or employee benefit plan shall require or permit the involuntary retirement of any individual specified by section 631(a) of this title because of the age of such individual; or

(3) to discharge or otherwise discipline an individual for good cause. ${ }^{19}$

An examination of these sections and the interplay between them is necessary before discussing the legislative history and the interpretation that has been given to section $4(f)(2)$.

As the language of sections $4(a)(1)$ and $4(a)(2)$ makes clear, in order to constitute a violation of the ADEA, the different treatment of an older worker must be "because of" age. ${ }^{20}$ Consequently, a showing

19 This is the current version of $\S 4(\mathrm{f})$, which was amended in 1978, see Pub. L. No. 95-256, § 2(a), 92 Stat. 189, 189 (1978), and in 1984, see Pub. L. No. 98-459, $\S$ 802(b)(1), 98 Stat. 1792, 1792 (1984).

${ }_{20}$ See, e.g., Golomb v. Prudential Ins. Co., 688 F.2d 547, 550 (7th Cir. 1982) ("IT]o establish a cause of action under the ADEA, a claimant must show that he was discriminated against because of his age."). 
that the allegedly discriminatory actions are not because of age is a complete defense to any charge of violating the ADEA. ${ }^{21}$ In many situations, however, the motive for an action consists of both age and nonage components. In these instances, the person alleging the violation must show that age is the determining factor in the decision. ${ }^{22}$

Whereas section 4(a) makes discrimination because of age unlawful, section $4(f)$ denotes specific situations in which differential treatment of older workers is lawful. An employer complies with section $4(f)(2)$ by spending the same amount on benefits for older workers as for other employees, even if those equal expenditures do not provide equal benefits. ${ }^{23}$ For example, because the cost of term life insurance increases with the age of the person covered, a $\$ 1000$ expenditure may purchase $\$ 100,000$ of coverage for a thirty-year-old employee, but only $\$ 75,000$ of coverage for a sixty-year-old employee. An employer spending $\$ 1000$ on each worker satisfies the ADEA, even though the older worker receives less insurance coverage. In contrast, spending $\$ 900$ for the older worker and $\$ 1000$ for the younger employee would not be protected by section $4(f)(2)$. If this different expenditure were because of age, it would violate the ADEA. ${ }^{24}$

The remainder of this Comment focuses on section $4(f)(2)$, specifically the interpretation of the phrase "employee benefit plan, such as a retirement, pension, or insurance plan." It is clear that section $4(f)(2)$ is not intended to make lawful employee benefit plans that make unequal expenditures for older workers. Nevertheless, it is unclear which interpretation of its terms best achieves this result.

21 See Britt v. E.I. du Pont de Nemours \& Co., 768 F.2d 593, 594 (4th Cir. 1985) (holding that a voluntary reduction in force plan does not constitute discrimination because of age); Parcinski v. Outlet Co., 673 F.2d 34, 36 (2d Cir. 1982), cert. denied, 459 U.S. 1103 (1983) (no age discrimination occurred where defendant eliminated a department without regard to employees' ages).

${ }^{22}$ See, e.g., Duffy v. Wheeling Pittsburgh Steel Corp., 738 F.2d 1393, 1395 (3d Cir. 1984) (Plaintiff "need not prove that age was the employer's sole or exclusive consideration, but must prove that 'age made the difference' in that decision." (citation omitted), cert. denied, 469 U.S. 1087 (1984); Geller v. Markham, 635 F.2d 1027, 1035 (2d Cir. 1980) ("Where an employer acts out of mixed motives . . . the plaintiff must show that age was a causative or determining factor . . . ."), cert. denied, 451 U.S. 945 (1981).

${ }^{23} \mathrm{See}$, e.g., Age Discrimination in Employment Interpretations, 29 C.F.R. $\S 860.120(a)(1)$ (1986) (A benefit plan satisfies $\S 4(f)(2)$ if "the actual amount of payment made or cost incurred, in behalf of an older worker is equal to that [for] a younger worker, even though the older worker may thereby receive a lesser amount of benefit or insurance coverage.").

24 It should, however, be noted that being outside $\S 4(f)(2)$ does not settle the question of violating the ADEA. Section 4(f)(1) might protect the different expenditure or it may be interpreted not to violate $\$ 4(a)$. 


\section{INTERPRETING SECTION 4(f)(2)}

\section{A. Legislative History}

The first step in properly interpreting the terms of section $4(f)(2)$ is to examine the legislative history of the provision. ${ }^{25}$ The following discussion details all of the Senate hearings pertinent to section $4(f)(2)$. Because they occurred before the House hearings ${ }^{28}$ and because section $4(f)(2)$ in its final form was reported by the Senate subcommittee, ${ }^{27}$ only the Senate hearings are discussed.

None of the original age discrimination bills contained an exception for actions taken under employee benefit plans. ${ }^{28}$ Senator Javits expressed the need for an exception on the first day of the Senate hearings on the proposed legislation. ${ }^{28}$ Senator Javits noted that the benefits payable to employees under some pension plans are "based to a certain extent on the age of the employee when first hired." ployers with these kinds of plans to provide equal pension benefits to older workers might discourage their employment because such benefits cost more for older than younger workers. ${ }^{\text {s1 }}$ Therefore, Senator Javits proposed that the bill give employers flexibility to structure the benefits under their pension plans to reflect the higher cost of providing benefits

25 See N. Singer, Sutherland Statutory Construction $\S 48.03$ (4th ed. 1984).

26 The Senate held hearings March 15-17, 1967; the House held hearings August 1-17, 1967.

27 See infra note 49 and accompanying text.

28 Compare S. 830, 90th Cong., 1st Sess. (1967), reprinted in Age Discrimination in Employment, 1967: Hearings on S. 830 and S. 788 Before the Subcomm. on Labor of the Senate Comm. on Labor and Public Welfare, 90th Cong., 1st. Sess. 6-7 [hereinafter Senate Hearings] (§ 4(f)(2) not present) with Pub. L. No. 90-202, 81 Stat. 602 (1967) (codified as amended at 29 U.S.C. $\$ 621-34$ (1982 \& Supp. III 1985)). The bill eventually enacted with amendments was S. 830, 90th Cong., 1st Sess. (1967). The House considered the identical bill as H.R. 4221, 90th Cong., 1st Sess. (1967). Section $4(f)(2)$ of these bills permitted "an employer, employment agency or labor organization . . . to separate involuntarily an employee under a retirement policy or system where such policy or system is not merely a subterfuge to evade the purposes of this Act." Senate Hearings, supra, at 6-7; Age Discrimination in Employment, 1967: Hearings on H.R. 3651, H.R. 3768, and H.R. 4221 Before the Subcomm. on Labor of the House Comm. on Education and Labor, 90th Cong., 1st Sess. 2-3 (1967) [hereinafter House Hearings].

20 See Senate Hearings, supra note 28, at 24 (prepared statement of Sen. Javits); see also id. at 27 (testimony of Sen. Javits).

so Id. at 24 (prepared statement). This statement suggests that Senator Javits was concerned with actions taken under defined benefit pension plans. Under defined benefit pension plans it is more expensive to provide the same level of benefits for older workers. Nevertheless, a large body of retirement plans-defined contribution plans-do not have such an age-related cost relationship. These issues are discussed more fully infra notes $122-30$ and accompanying text.

31 See Senate Hearings, supra note 28, at 24 (prepared statement). 
to older workers, thereby removing any inherent disincentive to employing older workers. ${ }^{32}$

Immediately following Senator Javits, Senator Smathers, a sponsor of Senate Bill $830,{ }^{33}$ one of the age discrimination bills, addressed the subcommittee and advocated an exception for employee benefit plans. ${ }^{34}$ He noted that the bill before the committee might be interpreted to require that workers hired between the ages of forty-five and sixtyfive $^{\mathrm{s5}}$ receive "private pension rights and other fringe benefits" identical to those provided to younger workers, thus ignoring the fact that benefits for older workers are more expensive. ${ }^{36}$ To avoid this possible problem, Senator Smathers proposed the following amendment to Senate Bill 830:

(g) Nothing in this Act shall be construed to make unlawful the varying of coverage under any pension, retirement, or insurance plan or any plan for providing medical or hospital benefits for work injuries, where such variance is necessary to prevent the employer's being required to pay more for coverage of an employee than would be required to provide like coverage for his other employees. ${ }^{37}$

Although the Smathers amendment was not adopted as part of the ADEA, it was the first mention that an employee benefit provision might cover programs other than pension or retirement plans.

As part of the same hearings, the subcommittee received a prepared statement from a leading employee benefit consulting firm ${ }^{\mathbf{3 8}}$ suggesting a broadening of unamended section $4(f)(2)$. This statement recommended that retired employees within the ages covered by the ADEA not be required to receive identical "employee benefits, such as group life insurance, medical benefits, etc." as still-employed workers of the same age. ${ }^{39}$ It proposed that in addition to the bill's exception for

32 See id. (prepared statement).

ss See supra note 28.

st See Senate Hearings, supra note 28, at 29-30 (testimony of Sen. Smathers).

ss Senate Bill 830 protected workers between these ages. Id. at 15-16. As finally enacted, the bill protected workers between 40 and 65 . See supra note 3 .

${ }^{38}$ See Senate Hearings, supra note 28, at 29-30 (testimony of Sen. Smathers).

s2 Id. at 30 .

s8 See id. at 279-80 (prepared statement of Charles S. Manning, Executive Vice President, Towers, Perrin, Forster \& Crosby, Inc.). The identical statement was presented to the House subcommittee. See House Hearings, supra note 28, at 496-97.

so Senate Hearings, supra note 28 , at 279 . Many employers continue benefits for retired workers, often at reduced levels. See THE HANDBOOK OF EMPLOYEE BENEFITS: Design, Funding and Administration 64 (J. Rosenbloom, ed. 1984) [hereinafter EMPLOYEe BENEFITS] (continuation of life insurance); J. RosenblOOM \& G. Hallman, Employee Benefit Planning 208-12 (1981) (continuation of health benefits). 
mandatory retirement under a bona fide retirement or pension plan, it be amended to exclude its application "to the operation of the terms or conditions of any other bona fide employee benefit plan." 40 Because the phrase "bona fide employee benefit plan" is part of section $4(f)(2)$ as enacted, it is important to note its use here to describe fringe benefit programs including, but not limited to, retirement or pension plans.

Representatives of the insurance industry were next to address the subcommittee." They feared that the proposed legislation went "beyond matters related to hiring and discharging of older workers"42 and threatened traditional underwriting practice and the stability of costs for benefits. ${ }^{43}$ The industry's representatives noted the broad use of age-related cost factors in the funding of benefit programs and the determination of benefit levels, and they proposed "that the legislation be amended to make clear that it would not affect the establishment or operation of the terms or conditions of any bona fide retirement, pension, employee benefit or insurance plan."44 This language indicates they also believed that "employee benefit plans" encompassed more than retirement, insurance, or pension plans.

The final testimony on section $4(f)(2)$ came from the American Telephone and Telegraph Company, ${ }^{4}$ which feared that its formula for pension eligibility would violate the ADEA. Eligibility depended on the employee having worked a minimum number of years and having

The concern addressed by the proposed amendment arises if a plan permits normal retirement before the maximum age covered by the ADEA. For example, assume a retirement plan allows normal retirement at age 62 and further permits a retiree to continue to receive benefits at a reduced level. Without the proposed amendment, a 63year-old retiree might have to receive the same benefits as a 63-year-old who is still working, thereby greatly increasing the cost for retiree's the benefits. The regulations for $\S 4(f)(2)$ resolve this issue by making lawful the reduction or cessation of life and health insurance for retirees. See Age Discrimination in Employment Interpretations, 29 C.F.R. $\S 860.120$ (f)(i), (ii)(G) (1986). Presumably these regulations would, by analogy, permit cessation of other insurance coverages. This situation of having active workers and retirees who are the same age should become more common now that the ADEA has no maximum age.

10 Senate Hearings, supra note 28 , at 280.

11 Id. at 295-97 (joint prepared statement of the American Life Convention, the Health Insurance Association of America, and the Life Insurance Association of America).

${ }^{12}$ Id. at 296. The same organizations presented to the House subcommittee a statement virtually identical to that given to the Senate subcommittee. Compare House Hearings, supra note 28, at 498-500, with Senate Hearings, supra note 28, at 295-97. The most significant difference was that the amendment proposed to the House mirrored the language that had been adopted by the Senate committee. See House Hearings, supra note 28 , at 499 . This language became the final version of $\S 4(f)(2)$.

is See Senate Hearings, supra note 28 , at 296.

14 Id. Co.).

45 See id. at 315-17 (prepared statement of American Telephone \& Telegraph 
attained a given age. ${ }^{48}$ The employer doubted whether the unamended bill would invalidate this formula ${ }^{47}$ but proposed amending section $4(f)(2)$ to eliminate any doubt. Under the proposed amendment, actions would be lawful if done in observance of "the terms and conditions of a retirement policy or system where such policy is not merely a subterfuge to evade the purpose of this Act or to provide varying insurance coverage according to an employee's age."48

Those who addressed the subcommittee, including sponsors of both bills under consideration, therefore, appeared to believe that any employee benefit exception should cover plans other than pension, retirement, and insurance plans. The bill reported by the Senate subcommittee contained section $4(f)(2)$ in its final form. ${ }^{49}$ The bills introduced for debate in both the Senate and House contained the final language. ${ }^{50}$ The Committee Report" explained that section 4(f)(2) "serves to emphasize the primary purpose of the bill-hiring of older workers-by permitting employment without necessarily including such workers in employee benefit plans. The specific exception . . . is considered vita [sic] to the legislation . . . ." It further stated that the purpose of the ADEA was to "promote the employment of older workers based on their ability." "Ds Despite these direct statements of the purposes of the ADEA and section 4(f)(2), neither the legislative history nor floor debates indicate Congress's intended interpretation of the terms of section

16 See id. at 316. For example, any employee could retire if she had 15 years of service and were 65 years old.

47 See id. at 317.

48 Id. This language was taken from the New York state law barring age discrimination, and the reader is referred to the current N.Y. ExEc. LAw $\S 296(3-a)$ (a) (McKinney 1982). The same statement was presented to the House committee, but the proposed amendment was changed to conform with $\S 4(f)(2)$ as passed by the Senate subcommittee. See House Hearings, supra note 28, at 494-96.

49 See House Hearings, supra note 28, at 499 (joint prepared statement of the American Life Convention, the Health Insurance Association of America, and the Life Insurance Association of America proposing an amendment identical to $\S 4(f)(2)$ in its final form) ("We understand that such an amendment to companion bill, S.830, has been approved by the Labor Subcommittee of the Senate.").

so See 113 Cong. REC. 34,739, 34,754 (1967).

51 The bill finally enacted as the ADEA was the Senate bill, after the Senate had adopted the language of the House bill. See 1967 U.S. Code Cong. \& ADMIN. NEwS 2213, 2213. Therefore, only the House report was published.

${ }^{32}$ H.R. ReP. No. 805, 90th Cong., 1st Sess. (1967), reprinted in 1967 U.S. Code Cong. \& Admin. News 2213, 2217; see also 113 Cong. Rec. 31,255 (1967) (including statements by Sen. Javits and Sen. Yarborough clarifying the purpose and scope of $\S 4(f)(2))$.

ss H.R. ReP. No. 805, 90th Cong., 1st Sess. (1967), reprinted in 1967 U.S. Code Cong. \& ADMIN. News 2213, 2214. The same language appears in 29 U.S.C. $\S 621$ (b) (1982). The ADEA is age-neutral; it also prohibits discrimination in favor of older workers. See 113 Cong. REC. 31,255 (1967) (statement of Sen. Yarborough). 
4(f)(2), including what kinds of benefit schemes are "bona fide employee benefit plans, such as retirement, pension, or insurance plans."

\section{B. Administrative and Judicial Interpretations}

\section{Administrative Interpretations}

Any interpretation of the terms of section $4(f)(2)$ must be consistent with two parameters inherent in the statute: (1) the ADEA prohibits only discrimination on the basis of age ${ }^{54}$ and (2) Congress intended section $4(f)(2)$ to permit reduced benefits for older workers where the cost of providing the benefits is tied to the employee's age. ${ }^{.5}$ There are several possible ways of interpreting the terms of section 4(f)(2) that would achieve the overall result intended by Congress: a plan providing lesser benefits to older workers, but lacking an inherent age/cost relationship, could be designated as not "bona fide," or not an "employee benefit plan, such as a retirement, pension, or insurance plan," Any of these classifications would deny the plan protection under section $4(f)(2) .{ }^{59}$ Because of the lack of guidance in the legislative history, the courts and administrative agencies reasonably could have selected any of these possibilities without reaching results contrary to Congress's intent. The remainder of this section examines how these bodies have interpreted the "employee benefit plan, such as a retirement, pension, or insurance plan" and "subterfuge" clauses of section 4(f)(2).

The pertinent regulations-similar to the legislative history-provide little guidance in interpreting the phrase "employee benefit plan, such as a retirement, pension, or insurance plan." They do, however, provide an objective test for "subterfuge to evade the purposes of [the Act]."

st See supra notes 20-22. text.

ss See 29 C.F.R. § 860.120(a)(1) (1986); supra notes 29-53 and accompanying

bo See EEOC v. Great Atl. \& Pac. Tea Co., 618 F. Supp. 115 (N.D. Ohio 1985).

"7 EEOC v. Westinghouse Elec. Corp. ("Westinghouse P'), 725 F.2d 211, 223 (3d Cir. 1983), cert. denied, 469 U.S. 820 (1984).

s8 EEOC v. Home Ins., 672 F.2d 252 (1982).

69 Any combination of these interpretations would also achieve the desired result.

60 The original Act gave the Secretary of Labor responsibility for administration. Pub. L. No. 90-202, §§ 6-7, 81 Stat. 602, 604 (1967). These duties were transferred to the Equal Employment Opportunity Commission (EEOC) in 1979. See Reorg. Plan No. 1 of 1978, 3 C.F.R. 321 (1978), reprinted in 5 U.S.C. app. at 1155 (1982), and in 92 Stat. 3781 (1978), enacted pursuant to the Reorganization Act of 1977, 5 U.S.C. $\S 901-912$ (1982). The original ADEA regulations were issued by the Department of Labor on June 21, 1968, see 33 Fed. Reg. 9172 (1968). A proposed interpretive bulletin for new regulations was issued in 1978, see 43 Fed. Reg. 43,264-70 (1978). The 
4(f)(2) was to permit cost-justified reductions in benefits for workers of different ages, give the example that paid vacations and uninsured paid sick leave programs are not covered by section $4(f)(2)$ because "reductions in these benefits would not be justified by significant cost considerations." ${ }^{\text {A1 }}$ According to the regulations, therefore, it would violate the ADEA for an employer to provide differing numbers of paid vacation or sick leave days to employees of different ages solely on the basis of age. ${ }^{62}$ The regulations do not explicitly state whether such programs fall outside section $4(\mathrm{f})(2)$ because they are not "employee benefit plans, such as retirement, pension, or insurance plans" or because they are "subterfuge[s] to evade the purposes of [the Act]." Closer examination reveals that the regulations implicitly label them as subterfuges. ${ }^{6 s}$

The majority of the regulations explain the ways of determining if a plan is a "subterfuge," including the appropriate means for showing a cost justification for any reduction in benefit levels. "In general, a plan ... which prescribes lower benefits for older employees on account of age is not a 'subterfuge' within the meaning of section $4(f)(2)$, provided that the lower level of benefits is justified by age related cost considerations." any plan with lesser benefits for older workers not justified by agerelated costs, such as a sick leave or paid vacation plan, is necessarily a subterfuge to evade the purposes of the ADEA. ${ }^{68}$ The regulations de-

final interpretive bulletin along with the current regulations was promulgated May 25 , 1979, see 44 Fed. Reg. 30,648-62 (1979) (regulations codified at 29 C.F.R. 860 (1986)). The EEOC took over administration of the ADEA on July 1, 1979. The current regulations took effect before the transfer occurred. See King, The ADEA and Employee Benefit Plans-Part II, 56 N.Y. ST. B.J. 19, 20 (1984). When the EEOC issued new regulations, it specifically left the employee benefit section undisturbed. See 29 C.F.R. § 1625.10 (1981).

${ }_{61} 29$ C.F.R. $\$ 860.120(a)(1)$ (1986). ("The legislative history of this provision indicates that its purpose is to permit age-based reductions in employee benefit plans where such reductions are justified by significant cost considerations.").

${ }^{62}$ Employees may receive different vacation allotments based on other factors, such as years of service. For example, a 42-year-old employee with 20 years of service may lawfully receive more vacation than a 62-year-old employee with 5 years of service.

os But see 44 Fed. Reg. 30,648 (1979) (The final interpretive bulletin issued with the 1979 regulations suggests that these benefits would not be "employee benefit plans.").

See 29 C.F.R. $\S 860.120$ (d) (1986).

${ }^{\circ 5}$ Id.

6o If the cited statement is accepted as true, its contrapositive must also be true: if the lower level of benefits provided by a plan or plan provision is not justified by agerelated cost considerations, the plan or plan provision is a "subterfuge." See, e.g., $\mathbf{R}$. Ackermann, Modern Deductive Logic: An Introduction to its Techniques AND SIgNIFICANCE 20 (1970) (discussing assertions and negative assertions); J. VENN, The PRINCIPLes of EMPIRICAL OR INDUCTIVe LoGic 219-39 (1907) (discussing the formation and deduction of sound propositions). 
fine "employee benefit plan" as "a plan, such as a retirement, pension, or insurance plan, which provides employees with what are frequently referred to as 'fringe benefits.' The term does not refer to wages or salary in cash." ${ }^{\text {"67 }}$ Because the term "fringe benefit" is equally as ambiguous as the term "employee benefit plan," this definition provides little assistance in interpreting "employee benefit plan." In addition, by defining "employee benefit plan" with reference to retirement, pension, or insurance plans, the regulations render the statutory phrase "such as a retirement, pension, or insurance plan" repetitious and purely descriptive, in no way limiting the boundaries of section 4(f)(2). Any plan that is an "employee benefit plan" is also, therefore, by definition an "employee benefit plan, such as a retirement, pension, or insurance plan." Finally, the regulations give no guidance in deciding if a "plan" is present.

\section{Judicial Interpretations}

The Fifth Circuit had the first opportunity to interpret the language "employee benefit plan, such as a retirement, pension, or insurance plan." In Brennan v. Taft Broadcasting Co., 88 the employer mandatorily retired an employee pursuant to the company's "Profit Sharing Retirement Plan." claiming that because the retirement plan's costs were independent of the ages of the covered employees, it was not the kind of plan Congress intended to bring under section $4(\mathrm{f})(2)$. The Fifth Gircuit held that the

This discussion of the subterfuge language ignores the regulations' use of the term "in general," which suggests that there may be some situations in which a benefit plan providing reduced benefits to older workers for a reason other than age-related costs would not be a subterfuge. Careful analysis, however, demonstrates that providing reduced benefits under a plan without age-related costs must always be classified as a subterfuge and that the regulations' use of the term "in general" is incorrect. The statutory language speaks of a "subterfuge to evade the purposes of [the Act]." The purpose of the ADEA was to prohibit age-motivated discrimination in employment. Therefore, reduced benefits for older workers are a subterfuge only if they result from age-based discrimination. Examined independently from the purpose of $\S 4(f)(2)$, any plan with a non-age-related reason for reducing benefits apparently would not be a subterfuge. The subterfuge language must be read in the context of the purpose of $\S 4(f)(2)$, which was to permit reductions only if justified by age-related costs. See N. Singer, supra note $25, \S 47.28$. In this context, the permissible non-age reasons for reduced benefits are limited: although a non-age reason may exist, reduced benefits under the plan are a subterfuge unless that reason is an age-related cost factor.

o7 29 C.F.R. \& 860.120(b) (1986).

500 F.2d 212 (5th Cir. 1974).

60 Id. at 214 . Under the plan, $10 \%$ of the company's annual profits were paid to the retirement fund trustee, "who distribute[d] these funds to plan members upon their retirement." Id. Because the sole determinant of the employer's cost was the amount of corporate profits, there was no age-related cost. 
profit-sharing retirement plan was an "employee benefit plan, such as a retirement, pension, or insurance plan" but offered no criteria for this classification. ${ }^{70}$ The court determined that in interpreting the statute, "[t]he key phrase is 'employee benefit plan'. The words, 'retirement, pension, or insurance', are added in a clearly descriptive sense, not excluding other kinds of employee benefit plans if, conceivably, there could be any." ${ }^{\prime 71}$ It refused to adopt the age-related cost test advocated by the Secretary of Labor, finding that, because the statutory language was unambiguous, there was no need to consider Congress's intent. ${ }^{72}$ Brennan raised several issues that have remained unsettled in the later cases involving section 4(f)(2): Is the language of the section unambiguous or should courts look to the legislative history of the ADEA for its interpretation? If they do, does the legislative history give any guidance? Is the phrase "such as a retirement, pension, or insurance plan" merely descriptive, or does it limit the kinds of plans covered by section $4(f)(2)$ ?

The next case interpreting "employee benefit plan, such as a retirement, pension, or insurance plan," Alford v. City of Lubbock, ${ }^{73}$ also arose in the Fifth Circuit and gave that court the opportunity to explore further the issues raised in Brennan. Alford was the first federal appellate court decision holding that a plan was not an "employee benefit plan, such as a retirement, pension, or insurance plan." The plaintiffs were two workers denied reimbursement for accumulated sick

70 See id. at 215-16. The court then held that because the plan had begun prior to the enactment of the ADEA, it could not be a subterfuge. Id. at 215. This interpretation has been referred to as the "chronological" approach. Congress rejected this interpretation of "subterfuge" in the 1978 amendments to the ADEA. See generally Note, Federal Age Discrimination in Employment Act: The Pension Plan Exception After McMann and the 1978 Amendments, 54 Notre DAME LAw. 323, 326-28 (1978) (discussing the "chronological" approach to interpreting "subterfuge").

71500 F.2d at 215 (emphasis added).

${ }^{72}$ Id. at 216 ("[I]f Congress meant terms in a statute to have other than their ordinarily accepted meaning, it would and should have given them a special meaning by definition." ") (quoting NLRB v. Highland Park Mfg. Co., 341 U.S. 322, 325 (1951)).

In adopting this interpretation, the Fifth Circuit relied on the Supreme Court's decision in Braunstein v. Commissioner, 374 U.S. 65 (1963). The Braunstein Court "thought it improper to consider Congressional purpose when the meaning of a statute is plain. And, the Court pointed to the practical difficulty of deciding, on a case by case basis, whether a given course of conduct is within the Congressional purpose." 500 F.2d at 217. Furthermore, the Fifth Circuit found that the language of a statute should be interpreted to indicate clearly the scope of the unlawful behavior being regulated. When the language is unambiguous, it would "hardly [be] reasonable to require persons affected by legislation to delve into voluminous and conflicting collections of speeches to determine whether what a statute plainly says is what it really means." Id.

73 664 F.2d 1263 (5th Cir.), cert. denied, 456 U.S. 975 (1982). 
leave when they retired. ${ }^{74}$ Their suit alleged, inter alia, that the employer's refusal to pay for the accumulated sick leave violated the ADEA. ${ }^{75}$ The defendant asserted that because the sick pay program was part of its overall employee benefit plan, the refusal to pay was protected by section $4(f)(2) .{ }^{76}$ The Fifth Circuit first clarified its finding in Brennan that the statutory phrase "such as a retirement, pension, or insurance plan" did not exclude "other kinds of employee benefit plans if, conceivably, there could be any." "'77 It said that this statement "did not suggest that [section] $4(f)(2)$ exempt[ed] all fringe benefits from scrutiny under the Act"; $; 8$ rather, the Alford court noted that Congress added section $4(f)(2)$ to protect complex benefit plans from scrutiny under the ADEA. ${ }^{79}$ Applying this standard to the sick pay program in Alford, the court held that the sick pay program was "a simple fringe benefit" not excepted by section $4(f)(2)^{80}$ but gave no objective criteria for distinguishing "complex" plans from "simple" ones.

Alford introduced the idea that an individual benefit program might receive different treatment under section $4(f)(2)$ if it were considered as part of a larger, integrated benefit scheme. The court "d[id] not believe that Congress, in developing the ADEA exemption for employee benefit plans, . . . meant to countenance the discriminatory dis-

34 Id. at 1265. Retiring employees hired before age 50 were paid for up to 90 days of accumulated sick leave. See Alford v. Gity of Lubbock, 484 F. Supp. 1001, 1004 (N.D. Tex. 1979), affd in part and rev'd in part, 664 F.2d 1263 (5th Cir.), cert. denied, 456 U.S. 975 (1982). Employees, such as the plaintiffs, hired after reaching age 50 received no payment for accumulated sick leave when they retired. Id. In addition, neither plaintiff received pension benefits because employees hired after age 50 were ineligible for pensions under the pension plan. Id. at 1003.

7B $484 \mathrm{~F}$. Supp. at 1004 . The plaintiffs asserted that the denial of pension benefits violated the ADEA and was not protected by $\S 4(f)(2)$ because the pension plan was not bona fide and was a subterfuge. Id. at 1005. Both the district court, $484 \mathrm{~F}$. Supp at 1005 , and the Fifth Circuit, 664 F.2d at 1271, rejected these claims. The plaintiffs also asserted state and federal constitutional claims that were rejected. See 664 F.2d at 1266-67.

${ }^{78} 664$ F.2d at 1271-72.

27 Id. at 1272 (quoting Brennan v. Taft Broadcasting Co., 500 F.2d 212, 215 (5th Cir. 1986)); see supra text accompanying note 71.

78664 F.2d at 1272 n.10.

29 See id. at 1272 ("Congress devised section $4(f)(2)$ in order to postpone any disruptive effects upon the many complicated pension plans already in force at that time until it could tackle the issue in more considered and comprehensive legislation.").

${ }^{80}$ Id. The Fifth Circuit refused to consider the sick pay program part of an integrated benefit plan because it was "not contained in the [pension plan] and [was] functionally irrelevant to any 'retirement, pension or insurance plan.' "Id. The sick pay program's only connection with the pension plan was the coincidence that both denied benefits to employees hired after age 50 . See $i d$. In a footnote, the court stated that the profit sharing retirement plan in Brennan was a "complex retirement package protected by the Act." Id. at 1272 n.10. 
pensation of all fringe benefits whether or not they are part of a specific and established 'benefit plan.' "81 This language suggested that, even though a fringe benefit program did not by itself fall under section $4(f)(2)$ (what here will be called, "independently protected"), it might be protected if it were considered as part of an integrated benefit scheme. $^{82}$ In clarifying Brennan, the Fifth Circuit relied on Congress's intent, seemingly rejecting Brennan's finding that no resort to the legislative history was necessary. Nowhere in Alford does the Fifth Circuit require that a program have an age-related cost factor to qualify as an "employee benefit plan, such as a retirement, pension, or insurance plan." The court's silence on this issue suggests that it continued to adhere to Brennan's rejection of this idea. ${ }^{83}$ Under Alford, whether a fringe benefit program independently was protected by $4(f)(2)$ depended entirely on its complexity or simplicity.

The Third Circuit faced these issues a year later in EEOC $v$. Westinghouse Electric Corp. ${ }^{84}$ ("Westinghouse I"). The Westinghouse Electric Corporation ("Westinghouse") denied layoff income and benefits ("LIB") to retirement eligible employees when it closed its Belleville, New Jersey, plant in $1977 .^{\text {ss }}$ The applicable collective bargaining agreement required the company to offer LIB to "eligible employees" affected by a layoff or plant closing at any of its plants nationwide. These employees had the option to receive LIB payments as a lump sum payment or as weekly payments. ${ }^{88}$ Retirement-eligible employees

81 Id. at 1272 (emphasis added).

82 See id. at 1272.

ss See supra text accompanying note 72 .

84 725 F.2d 211 (3d Cir. 1983), cert. denied, 469 U.S. 820 (1984).

8s Id. at 213. Westinghouse denied LIB payments to 65 employees who were older than 55 and who had more than 10 years of service, and "summarily placed these employees on early retirement." See id. The company based these actions on its interpretation of the contractual term, "eligible employee." See id at 215; see also EEOC v. Westinghouse Elec. Corp., 577 F. Supp. 1029, 1042 (D.N.J. 1982), rev'd, 725 F.2d 211 (3d Cir. 1983), cert. denied, 469 U.S. 820 (1984).

86 715 F.2d at 214-15. Selecting the lump sum option required the employee to surrender all rights based on past service, except vested pension rights. See id. at 214 . The weekly payments supplemented the employee's unemployment compensation payments and did not require her to surrender any recall or service rights. Id.

The maximum amount of LIB that an employee received was the total maximum sum, which was "equal to [one] week's pay for each full year of . . . service with the company" but was never less than four week's pay. 577 F. Supp. at 1040. An employee selecting the lump option received the entire total maximum sum in one payment. Id. Under the weekly payment option, the employee received LIB payments to supplement unemployment compensation. LIB was paid in an amount so that the aggregate of LIB and unemployment compensation payments were $60 \%$ of the employee's weekly pay. LIB continued until either the total maximum sum was expended or 12 months had passed since the layoff. Id. at 1040-41. 
did not qualify as "eligible employees" for LIB. ${ }^{87}$

The EEOC filed suit on behalf of the retirement-eligible employees claiming that Westinghouse willfully violated section 4(a) of the ADEA by denying them LIB payments on the basis of their age. ${ }^{88}$ Westinghouse's defenses included a claim that its actions were lawful under section $4(f)(2){ }^{80}$ The district court granted summary judgment for Westinghouse on all the issues, including the $4(f)(2)$ defense. The district court also found that the LIB was part of Westinghouse's overall employee benefit scheme. ${ }^{90}$ The Third Circuit reversed and remanded the case on all counts. This court of appeals, relying on congressional intent, interpreted the phrase "such as a retirement, pension, or insurance plan" as limiting the scope of section 4(f)(2). Because it lacked any relationship between the age-of the covered employee and the cost of the benefits provided, ${ }^{01}$ the LIB program, considered independently, was not an "employee benefit plan, such as a retirement, pension, or insurance plan." "92 Despite citing Brennan in noting that it was "aware that the words 'such as retirement, pension, or insurance' were added in a descriptive sense, not excluding other kinds of employment benefit plans,"9s the court nevertheless concluded, "Even though these words are descriptive, their description contains substance. These words are to be interpreted as indicative of the types of plans in which Congress intended to allow age distinctions; they are of the type

87 725 F.2d at 214 . In order to qualify as an "eligible employee," a worker needed two or more years of service and could not be "entitled to early retirement as specified in the Westinghouse Pension Plan." 725 F.2d at 214; see also 577 F. Supp. at 1037 (discussing full requirements of "eligible employee"). Both the pension plan and LIB program were the result of collective bargaining and applied to all Westinghouse employees nationwide. See id. at 1034.

88725 F.2d at 215 . The employees sought both early retirement and LIB lump sum payments, which they claimed were severance pay. 577 F. Supp. at 1040 . The district court said the LIB was "a benefit plan to supplement unemployment insurance," not severance pay. Id. at 1039.

89 725 F.2d at 215 . Westinghouse also claimed that the suit was barred by the statute of limitations and that its actions were permissible under $\S 4(f)(1)$ because they were based on reasonable factors other than age. See id. at $215,217,222$.

${ }^{\circ 0}$ See 577 F. Supp. at 1041. The district court's finding is discussed more fully infra note 161 .

91 See 725 F.2d at 224 . The court correctly found that the LIB benefits received by an eligible employee did not depend on age but instead "[were] based solely on an employee's length of service-at least two years-and the occurrence of a layoff." Id. The court could "glean no age-related cost factor on the face of the LIB Plan which justifie[d] Westinghouse's actions." Id. at 224-25.

${ }_{92}$ Id. at 225 (The court likened the LIB plan to the sick leave plan in Alford, noting that both were "functionally independent" from the respective pension plans to which they were linked. As such, the plan would be individually subject to $\S 4(f)(2)$ scrutiny.).

${ }_{93}$ Id. at 224 (citing Brennan v. Taft Broadcasting Co., 500 F.2d 212, 215 (5th Cir. 1974)). 
whereby the cost of benefits increases with age." rectly conflicts with Brennan, Alford, and the district court decision in Westinghouse $I$, all of which refused to interpret the "such as" clause as a limitation.

In addition to rejecting the LIB program as an independently protected plan, the Third Circuit also refused to recognize it as part of Westinghouse's integrated benefit scheme. ${ }^{95}$ It stressed that the LIB program was "functionally independent" of the Westinghouse pension plan: "The mere fact that the benefits available to employees under the Pension Plan were to be considered when determining eligibility for LIB . . . does not merge the two plans into a single 'coordinated benefit plan." "This language suggests, however, that if the court had found the LIB to be part of a single, integrated benefit plan, it would have found it lawful under section $4(\mathfrak{f})(2)$. As in Alford, the court reached its conclusion without giving any criteria for evaluating whether a program was integrated.

For several reasons, the test announced in Westinghouse $I$ rests on questionable support. First, the Third Circuit introduced the idea that the set of "employee benefit plans" covered by section $4(f)(2)$ is limited to those with an age-related cost factor. The basis for this interpretation is unclear; no supporting authority is cited. Second, the court cites Brennan for the proposition that the "such as" clause is descriptive only, but the court immediately contradicts itself by finding that the words limit the class of "employee benefit plans." Third, the court says that retirement, insurance, and pension plans are the kinds of plans "in which Congress intended to allow age distinctions"gr but does not explain how it discerned Congress's intent. As was shown, the legislative history lacks any indication of the intended interpretation of "employee benefit plan, such as a retirement, pension, or insurance plan."98 Rather, any discussion in the legislative history was of the scope of the entire 4(f)(2) provision. Finally, the Third Circuit said, "[T]he thread common to retirement, insurance, and pension plans . . . is the age-

94 Id.

9s See id. at 225 ("Fringe benefit plans unrelated to the age cost factor are not included in the 4(f)(2) exception."). But see infra note 112 and accompanying text.

By refusing to recognize the LIB program as part of Westinghouse's benefit plan, the Third Circuit rejected a factual finding by the district court that the plans were interlocked. See EEOC v. Westinghouse Elec. Corp., 577 F. Supp. 1029, 1041

(D.N.J. 1982), rev'd, 725 F.2d 211 (3d Cir. 1983), cert. denied, 469 U.S. 820 (1984).

725 F.2d at 225 (citing EEOC v. Borden's, Inc., 551 F. Supp. 1095, 1099 (D. Ariz. 1982), affd, 724 F.2d 1390 (9th Cir. 1984)).

97 Id. at 224.

os See supra notes 28-53 and accompanying text. 
related cost factor." ${ }^{\prime 99}$ This statement is incorrect; many kinds of retirement and insurance plans do not have age-related costs. ${ }^{100}$

Almost concurrently with the Third Circuit decision in Westinghouse I, the Ninth Gircuit decided EEOC v. Borden's, Inc., ${ }^{101}$ which involved the denial of severance pay after a December 31, 1979, plant closing in Phoenix, Arizona. ${ }^{102}$ The severance pay program, which applied only to the Phoenix plant, was adopted in November 1979 as an addendum to the collective bargaining agreement that had been renewed in July 1979. ${ }^{103}$ It denied benefits to employees eligible for retirement. ${ }^{104}$ The existing retirement plan was not reopened during the negotiations over the severance pay policy. ${ }^{105}$ On behalf of fourteen employees denied severance pay, the EEOC filed suit under the ADEA. As one of its defenses, Borden's, Inc. asserted that the severance pay program fell under section $4(f)(2)$ because it "was connected with the existing retirement plan in such a way so as to create a 'coordinated benefit plan." "108 The district court rejected this claim ${ }^{107}$ and the Ninth

90 725 F.2d at 224.

100 See infra notes $121-30$ and accompanying text.

101724 F.2d 1390 (9th Cir. 1984). Westinghouse I was decided December 29, 1983; Borden's was decided January 31, 1984.

102 See id. at 1391.

108 Id. Identical severance pay provisions were added to collective bargaining agreements with two unions: Teamsters and Operating Engineers. Both the Teamsters and the Operating Engineers accepted the severance policy in November, 1979. See EEOC v. Borden's, Inc., 551 F. Supp. 1095, 1097 \& nn.1-2 (D. Ariz. 1982), affd, 724 F.2d 1390 (9th Cir. 1984).

104724 F.2d at 1391-92. Under the pension plan employees could retire at age 55 with 10 years service. The severance pay agreement denied payments "to any employee who at the time of termination is eligible for a normal or early retirement pension." 551 F. Supp. at 1097 n.2.

${ }_{108} 551$ F. Supp. at 1099; see also 724 F.2d at 1396 ("There is no evidence that the severance pay proposal caused the collective bargaining agreements to be renegotiated or affected them in any other way."). It is unclear when the plant closing was announced.

108551 F. Supp. at 1099; see also 724 F.2d at 1396 (The severance pay policy was an "integral part of its retirement and pension package.").

107 The district court relied on Alford in rejecting the employer's claim and noted that the "mere fact" that the available level of retirement plan benefits was considered in deciding on the severance pay formula did not merge the two plans. $551 \mathrm{~F}$. Supp. at 1099-1100. But see Patterson v. Independent School Dist., 742 F.2d 465, 467 n.3 (8th Cir. 1984) (questioning both the finding that the severance pay policy was independent of the overall employee benefit scheme and the reliance on Alford for this finding). The district court specifically declined to decide whether a severance pay policy such as Borden's could ever be part of an "employee benefit plan, such as a retirement, pension, or insurance plan." 551 F. Supp. at 1100.

Because Borden's' pleadings only claimed that the severance pay policy was part of its integrated benefit scheme, see 551 F. Supp. at 1099, the district court did not address the specific issue of whether the severance pay was independently an "employee benefit plan, such as a retirement, pension, or insurance plan." Nevertheless, its holding that $\S 4(f)(2)$ did not protect the severance pay plan implicitly answers that ques- 
Circuit affirmed. ${ }^{108}$

In finding that the phrase, "such as a retirement, pension, or insurance plan," was not intended to be a complete list of the plans covered by section $4(f)(2)$, the Ninth Circuit relied on the legislative history. ${ }^{109}$ It found that Congress's intent in enacting section $4(f)(2)$ was to "avoid disrupting pensions and other complex, on-going benefit schemes."110 Noting that the severance pay policy had been negotiated separately from the collective bargaining agreement, the court found it not to be part of a complex ongoing scheme; rather, the severance pay policy was a "'simple fringe benefit' outside the scope of [section $4(f)(2)]$." 111 Although it was hardly a model of clarity in this regard, Borden's thus was the first case to suggest objective criteria for evaluating an integrated benefit scheme: the ongoing nature of the benefit and the negotiation of the benefit along with the general collective bargaining agreement.

Although it denied protection to the severance pay plan, the Ninth Circuit said, however, that a "severance pay policy which is an integral part of a complex benefit scheme might be regarded differently." ${ }^{112}$ In addition, although the issue was apparently not contested by Borden's, Inc., ${ }^{118}$ the court also found that the severance pay plan was not independently protected by section $4(f)(2)$ because the cost of the severance pay benefits was unrelated to the age of the workers and because it was "a one-time, ad hoc cash payment," not an ongoing plan. ${ }^{114}$

After Westinghouse I and Borden's, courts, in evaluating claims that plans were independently protected, appeared to be in agreement that the legislative history was the proper place to find guidance in interpreting "employee benefit plan, such as a retirement, pension, or insurance plan." As was shown earlier, however, there was nothing in the legislative history to clarify how the terms of section $4(f)(2)$ were to be interpreted. ${ }^{115}$ In addition, the courts' interpretations of the "such as" clause were inconsistent: some courts treated this phrase as a limitation on "employee benefit plan" and others treated it as merely de-

tion in the negative.

108724 F.2d at 1396.

109 Id. at 1395 (phrase "suggests that Congress meant to exempt only certain benefit schemes from the antidiscriminatory provisions of the Act").

110 Id. at 1396.

111 Id. at 1397.

112 Id. at 1396-97 (citing Westinghouse I, 725 F.2d at 224-25). This citation to Westinghouse I suggests that the Ninth Circuit would have construed the LIB program to be part of a complex, integrated benefit structure.

113 See supra note 107.

114724 F.2d at 1396; see also supra note 107.

11 See supra notes 28-53 and accompanying text. 
scriptive. Most courts also had acknowledged that a benefit scheme should be treated differently under section $4(f)(2)$ depending on whether it was considered independently or as part of an integrated plan. They provided little guidance, however, in deciding whether a plan is part of an integrated benefit scheme. In the next Part, this Comment evaluates the age-related cost test proposed in Westinghouse I as applied to plans claiming independent protection and suggests an alternative test for deciding whether a plan is independently protected by section $4(f)(2)$. Part IV addresses the integrated plan issues.

\section{CRITICISM of Westinghouse I AND Borden's and Suggestion of an Alternative Test}

\section{A. Criticism}

Considerable confusion and disagreement over the proper interpretation of section 4(f)(2) followed EEOC v. Westinghouse Electric Corp. ${ }^{116}$ ("Westinghouse $\Gamma$ ") and EEOC v. Borden's, Inc. ${ }^{117}$ Section $4(f)(2)$ in its entirety only encompasses independent plans that have age-related costs. The Westinghouse $I$ test admittedly limits that section's coverage to these kinds of plans but creates problems and inconsistencies.

After Alford v. City of Lubbock ${ }^{118}$ and Brennan v. Taft Broadcasting Co.,"110 "employee benefit plans" were a subset of all possible fringe benefits. ${ }^{120} \mathrm{~A}$ program could exist, such as the sick pay plan in Alford, which was a fringe benefit but not an "employee benefit plan" as defined by section $4(\mathrm{f})(2)$. No further subdivision existed, however. This result followed directly from the conclusion that the phrase "such as a retirement, pension, or insurance plan" had no limiting force.

Under the Westinghouse I and Borden's interpretation, however, a further subset exists to which section $4(f)(2)$ is limited in its application. Consequently, a program can exist that is concededly an "employee benefit plan" as defined by the ADEA but that is not an "employee benefit plan, such as a retirement, pension, or insurance plan" within the protection of section 4(f)(2). This interpretation of the "such as" clause necessitates two tests: one for "employee benefit plan" and one for "employee benefit plan, such as a retirement, pension, or insur-

116725 F.2d 211 (3d Cir. 1983), cert. denied, 469 U.S. 820 (1984).

117724 F.2d 1390 (9th Cir. 1984).

118664 F.2d 1263 (5th Cir.), cert. denied, 456 U.S. 975 (1982).

110500 F.2d 212 (5th Gir. 1974).

130 The term fringe benefits refers to any nonsalary payments or in-kind services from an employer to an employee. 
ance plan." Westinghouse I and Borden's are flawed decisions because neither proposes a separate test for "employee benefit plan."

By excluding from section $4(f)(2)$ several benefits that are retirement or insurance plans, the age-related cost test creates an inconsistency in interpreting that provision. At a minimum, the terms of the statute bring pension, retirement, and insurance plans within the ambit of section $4(f)(2)$. Nevertheless, some retirement and insurance benefits commonly provided to employees lack age-related cost funding factors and therefore do not satisfy the Westinghouse $I$ test despite clearly falling within section $4(f)(2)$ 's coverage. ${ }^{121}$

There are two categories of retirement plans-defined benefit plans and defined contribution plans ${ }^{122}$ - but only defined benefit plans have age-related costs. ${ }^{128}$ Under a defined benefit plan, an employee's annual retirement benefit is calculated by applying a formula that usually factors in her salary and years of service. The plan pays a fixed annual benefit calculated at the time of retirement. The older the employee when hired, the less time available for funds to accrue to pay the promised benefit; therefore, it may be more expensive to hire older employees under a defined benefit plan. Most employees in the United States covered by the private pension system participate in defined benefit plans. ${ }^{124}$ The emphasis on age-related cost factors in the legislative

121 Any attempt to define an employee benefit plan by examining programs commonly considered "employee benefits" involves a degree of circular reasoning. Any nonsalary compensation or employer provided, in-kind service is open to a claim that it should be considered an employee benefit. These could range from company provided health insurance to free coffee for employees. This Comment assumes that certain programs are employee benefit plans based on the extent to which such benefits are provided pursuant to employment contracts (free coffee usually is not) and are by common understanding employee benefits. If the amendments suggested during the Senate hearings on the ADEA are indicative of what might constitute the "common understanding," it is clear that more than just pension, retirement, and insurance plans are employee benefits. See supra notes 29.44 and accompanying text.

122 See, e.g., 29 U.S.C. § 1002(34), (35) (1982); E. Allen, J. Melone \& J. Rosendloom, Pension Planning: Pensions, Profit Sharing, and Other Deferred Compensation Plans 57-64 (5th ed. 1984) [hereinafter Pension PlanNING]; Note, Age Discrimination in Employee Benefit Plans: Financial Dilemma for the Older Worker, 33 U. FLA. L. REv. 368, 385-87 (1981). Another way to categorize employee benefit plans is according to who funds the plan. If the employer pays all the costs, the plan is noncontributory, whereas if the employee assumes some or all of the cost, the plan is contributory. See J. Rosenbloom \& G. Hallman, supra note 39, at 431-34. This Comment considers only noncontributory plans, although its analysis may apply to many contributory arrangements.

${ }_{123}$ The employer relies on actuarial assumptions to estimate annual funding costs and assumes the risk that the amount of money funded during the worker's career may be insufficient to provide the promised retirement benefits. See EMPLOYEE BenefrTs, supra note 39, at 394-95.

124 See Special Comm. on Aging, Developments in Aging: 1985, S. Rep. No. 242, 99th Cong., 2d Sess. 42 (1986) ("Most private plan participants (70 percent) 
history suggests that Congress was most concerned with defined benefit plans when it enacted section $4(f)(2)$.

The second category of retirement plans are defined contribution plans. ${ }^{125}$ A variety of programs are defined contribution plans, including profit sharing, savings, thrift, and individual retirement account (IRA) plans. If these plans provide retirement benefits, they can be classified as defined contribution retirement plans. ${ }^{128}$ The employee's benefit depends solely on the growth of the invested funds; therefore, defined contribution plans do not have age-related costs. ${ }^{127}$ Consequently, a defined contribution retirement plan would not be within section $4(f)(2)$ under the Westinghouse I interpretation, despite the language of the statute bringing retirement plans under that section. Westinghouse $I$ creates a similar anomaly for some insurance benefits. The most commonly recognized employer-provided insurance programs are health, disability, and life insurance. ${ }^{128}$ The employer's cost for these programs usually increases with the age of the covered employee. ${ }^{129}$ Nevertheless, employers often provide insurance coverages for which age and cost are unrelated. These include prepaid legal services, and insurance for accidental death and dismemberment, personal liability, and loss or destruction of property. ${ }^{130}$

The Westinghouse I approach creates confusion and inconsistencies in evaluating whether certain retirement and insurance plans are independently "employee benefit plans, such as retirement, pension, and insurance plans." In addition, it fails to propose the separate test for "employee benefit plan" that its interpretation of the "such as"

are covered under a defined-benefit pension plan.").

${ }^{125}$ See Pension Planning, supra note 122, at 64 ("[T] plan has begun to take on a more significant role and this role is likely to become greater in the years ahead."); id. at 267 n.1 ("Over 80 percent of all new plans established since the passage of ERISA have been defined contribution in nature.").

${ }^{126}$ See, e.g., Brennan, 500 F.2d at 212 (profit sharing retirement plan); ЕмPloyee BenefiTs, supra note 39 , at 491 (thrift plan can be a defined contribution retirement plan).

${ }^{127}$ For a discussion of funding of defined contribution plans, see Pension PlanNING, supra note 122, at 86-89; EMPLOYEE BENEFITS, supra note 39, at 435; Schneyer, Employee Benefit Plans At A Glance, 5 ORANGe CounTy B.J. 277, 281-82 (1978).

${ }_{128}$ These are the insurance coverages specifically discussed in the regulations. See 29 C.F.R. \& 860.120(f)(1)(i)-(iii) (1986).

120 See id.

130 See EMPLOYEE BENEFITS, supra note 39, at 275-301 (Employers commonly provide automobile insurance, homeowner's insurance, and prepaid legal services as employee benefits.); Cohen, Section $4(f)(2)$ of the Age Discrimination in Employment Act: Age Discrimination in Employee Benefit Plans, 2 W. NEw ENG. L. REv. 379, 411-13 (1980) (discussing employee benefits in the form of accidental death and dismemberment insurance). But of. Amendment to Interpretive Bulletin, 44 Fed. Reg. 30,650 (1979) (prepaid legal services plan is not an "employee benefit plan"). 
clause necessitates. The next section proposes a test that produces results consistent with the purposes of the ADEA and section $4(f)(2)$ but avoids the problems of the Westinghouse I test.

\section{B. Proposed Test}

Rejecting Westinghouse I requires formulating a new test to determine whether an independent benefit scheme is an "employee benefit plan, such as a retirement, pension, or insurance plan." The legislative history lacks any direct indication of the types of plan this term encompasses and therefore gives no guidance for interpretation. Absent congressional guidance, or indications that the phrase "employee benefit plan" means something other than what it says, there is no basis for adopting the limited meaning espoused in Westinghouse $I$ and Borden's. Broader interpretation of this phrase would not automatically except all benefit plans from the ADEA, however, because of the regulations' vigorous test for "subterfuge."131 The regulations' definition of "subterfuge" independently invalidates those programs not eligible for section 4(f)(2) protection; thus, a narrow test for "employee benefit plan, such as a retirement, pension, or insurance plan," such as the one proposed in Westinghouse $I$, is unnecessary. No matter how broadly one interprets "employee benefit plan, such as a retirement, pension, or insurance plan," only those plans with cost-justified reductions in benefits survive the subterfuge test.

Consider, for example, a plan that has age-related costs and reduces benefits for older workers by an amount greater than that justified by the increased cost. This program is of the kind intended to fall outside of section $4(f)(2)$. It is a subterfuge under the regulations and properly is denied section $4(\mathrm{f})(2)$ protection, regardless of the definition of "employee benefit plan, such as a retirement, pension, or insurance plan." In contrast, a plan without age-related costs is a subterfuge only if it reduces benefits for older workers. A plan lacking agerelated costs and not reducing benefits for older workers has no differential treatment and therefore does not violate section 4(a). The regulations' subterfuge test would guarantee results consistent with the purposes of section 4(f)(2) and the ADEA, regardless of the interpretation of "employee benefit plan, such as a retirement, pension, or insurance plan."

181 It may be argued that the definition of "subterfuge" should include a subjective intent component. Analysis of this idea is beyond the scope of this Comment. For purposes of this Comment, it is assumed that the definition of subterfuge contained in the regulations is the proper definition. 
The next question is whether the "such as" clause further subdivides "employee benefit plan." If it does, two tests are necessary. Presumably, a single test is preferable if the results are not altered. Because the subterfuge test ensures that a single test will produce results consistent with the purpose of section $4(f)(2)$, and because the legislative history offers no contrary indication, the "such as" clause should not be interpreted as a limitation. As has been shown, there is ample authority for this interpretation of the "such as" language. ${ }^{132}$ Consequently, only a test for "employee benefit plan" is needed. The test selected should reflect better the common understanding of this phrase and should avoid the inconsistencies of the Westinghouse $I$ test.

The solution proposed here is the adoption of the ERISA definition of "employee benefit plan,"133 as did the district court in Westinghouse $I .{ }^{134}$ ERISA is the comprehensive federal statute regulating pensions and employee benefits. ${ }^{135}$ Arguably, it is the "place to fight [the pension] battle" to which Senator Javits said the ADEA should defer. ${ }^{138}$ If the results of the cases remain unchanged, a definition of "employee benefit plan" that is consistent with ERISA's definition is preferable. A court adopting this definition could argue that the ADEA and ERISA share the goal of ensuring solvency in employee benefit plans and are therefore in pari materia. ${ }^{\mathbf{1 3 z}}$ Alternatively, it could posit that it is merely adopting the "plain meaning" of "employee benefit plan" and that ERISA is the proper place to find this meaning.

ERISA separates employee benefit plans into welfare benefit plans and pension benefit plans. ${ }^{198}$ In general, pension benefit plans are those

132 See supra notes 67, 71, 77-79 and accompanying text; see also Cipriano v. Board of Educ., 785 F.2d 51, 54 (2d Cir. 1986); Patterson v. Independent School Dist., 742 F.2d 465, 466-67 (8th Cir. 1984).

1s3 See 29 U.S.C. \& 1002(1)-(3) (1982).

134 See 577 F. Supp. 1029, 1034 (D.N.J. 1982). At the time the current ADEA regulations were promulgated, it was suggested that $\S 4(\mathrm{f})(2)$ adopt the ERISA definition of employee benefit plan. See Amendment to Interpretive Bulletin, 44 Fed. Reg. 30,650 (1979). The suggestion was rejected because the ERISA definition "encompasse[d] plans which are maintained to provide vacation benefits, prepaid legal services and certain other benefits whose cost does not increase with the age of the employee participant." Id. A court owes limited deference to interpretive regulations issued by an administrative agency. See General Elec.v. Gilbert, 429 U.S. 125, 141-42 (1976) (citing Skidmore v. Swift \& Co., 323 U.S. 134, 140 (1944)); Note, The Effect of the Age Discrimination in Employment Act Employee Benefit Plan Exception on Small Businesses, 13 U.C. Davis L. Rev. 969, 994-95 \& nn.148-49 (1980).

135 New York Law Journal, Interpreting Pension Law Developments 3 (1976) (ERISA was the "first comprehensive non-tax regulation of "employee benefit plans' under the labor laws."). ERISA.

1se See Senate Hearings, supra note 28 , at 24 . Senator Javits was a cosponsor of

137 N. SINGER, supra note $25, \S 51.03$.

138 ERISA defines "employee benefit plan" as "an employee welfare benefit plan 
that provide post-employment income. ${ }^{139}$ Welfare benefit plans supply health benefits and "benefits in the event of sickness, accident, disability, death or unemployment, or vacation benefits . . . or prepaid legal services" to employees or retirees. ${ }^{140}$ To be either a pension or welfare benefit plan, the arrangement must be a "plan, fund, or program."141 The seminal case defining these terms, Donovan v. Dillingham, ${ }^{142}$ noted, "At a minimum, . . . a 'plan, fund, or program' under ERISA implies the existence of intended benefits, intended beneficiaries, a source of financing, and a procedure to apply for and collect benefits." 148 The ERISA interpretation gives broad scope to "employee benefit plan" and avoids the inconsistencies of Westinghouse $I$ because it encompasses all retirement, pension, and insurance plans. By statutory definition, defined benefit and defined contribution pension plans are employee benefit plans under ERISA. ${ }^{144}$ Courts also include retirement, ${ }^{145}$ disability, ${ }^{146}$ insurance, ${ }^{147}$ prescription, ${ }^{148}$ layoff, ${ }^{149}$ and severance $^{\mathbf{1 5 0}}$ programs within that definition but have refused to extend it to

or an employee pension benefit plan or a plan which is both an employee welfare benefit plan and an employee pension benefit plan." 29 U.S.C. § 1002(3) (1982).

${ }^{139}$ See 29 U.S.C. \$ 1002(2) (1982) (a pension benefit plan is "any plan, fund, or program which ... (i) provides retirement income to employees, or (ii) results in a deferral of income by employees for periods extending to the termination of covered employment or beyond").
16029 U.S.C. \& $1002(1)(1982)$.
141 See 29 U.S.C. \& 1002(1), (2) (1982).
142688 F.2d 1367 (11th Gir. 1982) (en banc).
14 Id. at 1372 .
144 See 29 U.S.C. $\$ 1002(34)$, (35) (1982).

148 See, e.g., Sreckovic v. International Harvester Co., 601 F. Supp. 332, 334 (N.D. Ill. 1984) (dictum stating that retirement plan included in definition of employee benefit plan); Commercial Mortgage Ins. Inc. v. Citizens Nat'l Bank, 526 F. Supp. 510,515 (N.D. Tex. 1981) (profit-sharing retirement plan included in definition of employee benefit plan).

${ }_{146}$ See, e.g., Roe v. General Am. Life Ins. Co., 712 F.2d 450, 452 (10th Cir. 1983) (permanent and total disability plan covered by ERISA); Hayden v. TexasUnited States Chem. Co., 557 F. Supp. 382, 384-85 (N.D. Tex. 1983) (same).

${ }_{142}$ See, e.g., Dependahl v. Falstaff Brewing Corp., 653 F.2d 1208, 1213-14 (8th Cir.), cert. denied, 454 U.S. 968 (1981) (entire life insurance plan within coverage of ERISA); Nolan v. Aetna Life Ins. Co., 588 F. Supp. 1375, 1377 (E.D. Mich. 1984) (group accident and health insurance policy regulated by ERISA).

${ }_{148}$ See Blue Cross \& Blue Shield v. Peacock's Apothecary, Inc., 567 F. Supp. 1258, 1267 (N.D. Ala. 1983) (prescription plan "part and parcel of ERISA 'employee benefit plans" ").

${ }_{149}$ See, e.g., McLendon v. Continental Group, Inc., 602 F. Supp. 1492, 1499 (D.N.J. 1985); Mamula v. Satralloy, Inc., 578 F. Supp. 563, 566 (S.D. Ohio 1983); EEOC v. Westinghouse Elec. Corp., 577 F. Supp. 1029, 1034 (D.N.J. 1982) (layoff income and benefit plan is a "welfare plan" within the terms of ERISA).

${ }^{160}$ See, e.g., Gilbert v. Burlington Indus., 765 F.2d 320, 325 (2d Cir. 1985), affd, 106 S. Ct. 3267 (1986); Scott v. Gulf Oil Corp., 754 F.2d 1499, 1502-04 (9th Cir. 1985) (severance pay policy is "welfare plan" under ERISA).

Cases holding severance pay to be an employee welfare benefit plan have relied on 
include accumulated sick pay programs. ${ }^{181}$

Under these decisions, the LIB of Westinghouse $I$, the severance pay of Borden's, and the retirement programs of Brennan would be employee benefit plans. Because none of these three programs have age-related costs, however, the differential treatment of older workers under these programs would be subterfuges under the ADEA regulations. Consequently, none of them independently is protected by section $4(f)(2) .{ }^{182}$ This result effectuates the purpose of section $4(f)(2)$ by limiting its protection to differential treatment under plans with inherent age-related cost factors. Regardless of the program claiming to be an "employee benefit plan," only those with age-related funding factors will satisfy the subterfuge test.

Because of the subterfuge test, the Westinghouse $I$ test adds nothing to the statutory interpretation and should be rejected. In every situation where the Westinghouse $I$ test would classify a plan as outside section $4(f)(2)$, the plan is also a subterfuge. The proposed test for "employee benefit plan" avoids the inconsistencies of the Westinghouse $I$ test and, when combined with the subterfuge test, produces results consistent with the purpose of section $4(f)(2)$.

\section{Integrated Benefit Plans}

Because any plan without age-related funding is a subterfuge and is easily identified, the test proposed above, if adopted, should reduce the number of litigated claims arguing that section $4(f)(2)$ independently protects a benefit program. Even if a litigant claims independent protection for a plan, a court can easily decide at the summary judg-

two alternative theories: (1) severance pay is an "unemployment" benefit within the meaning of 29 U.S.C. $\S 1002$ (1)(A) or (B) (1982), see, e.g., Gilbert, 765 F.2d at 325; Jung v. FMC Corp., 755 F.2d 708, 710 n.2 (9th Cir. 1985) (severance pay is an unemployment benefit within $\S 1002(1)(A)$ ); or (2) regulation 29 C.F.R. $\S 2510.3-$ (1)(a)(3) (1986) specifically brings severance pay into the definition of employee welfare benefit plans, see, e.g., Gilbert, 765 F.2d at 325; Blau v. Del Monte Corp., 748 F.2d 1348, 1352 (9th Cir. 1984) (regulation 29 C.F.R. § 2510.3-(1)(a)(3) (1986) "include[s] within the definition of 'welfare plan' those plans which provide holiday and severance benefits").

${ }_{161}$ See Abella v. W.A. Foote Memorial Hosp., Inc., 740 F.2d 4, 5 (1984) ("Department of Labor regulations expressly declare that sick leave benefits are excluded from the definition of "employee welfare benefit plan." ").

${ }_{182}$ The actions might be protected by another part of the ADEA or as part of an integrated benefit scheme. In addition to holding that $\S 4(\mathrm{I})(2)$ applied, the district court in EEOC v. Westinghouse Elec. Corp., 577 F. Supp. 1029, 1044 (D.N.J. 1982), rev'd, 725 F.2d 211 (3d Cir. 1983), cert. denied, 469 U.S. 820 (1984), stated that the LIB did not violate the ADEA because the employee made the decision not to receive the lump sum payment or, alternatively, because the denial relied on reasonable factors other than age. 
ment stage whether the claim is valid. ${ }^{153}$ Nevertheless, much uncertainty still exists as to whether a plan is part of an integrated benefit scheme. Because most employers provide more than one kind of benefit, ${ }^{154}$ the integration debate should become a primary battlefield for age discrimination claims involving employee benefits. A comprehensive analysis of whether integration claims are consistent with the purposes of section $4(f)(2)$ is beyond the scope of this Comment, ${ }^{155}$ but this Part proposes several considerations that should be relevant to deciding whether an integrated benefit scheme exists. The application of these proposed criteria is demonstrated by using them to evaluate $E E O C v$. Westinghouse Electric Corp. ${ }^{150}$ ("Westinghouse P") and EEOC v. Borden's, Inc. ${ }^{187}$

One important consideration should be the presence of collective bargaining. Collective bargaining units frequently negotiate for a package of benefits and salary. Trade-offs are inherent in this process. ${ }^{168}$

15s The court needs only look to the funding structure of the plan to decide if it is a subterfuge. This structure should rarely be in dispute, so summary judgment will be appropriate if there is no age-related cost factor.

104 See, e.g., Distribution and Economics of Employer-Provided Fringe Benefits: Hearings Before the Subcomm. on Social Security and Subcomm. on Select Revenue Measures of the House Comm. on Ways $\mathcal{E}$ Means, 98th Cong., 2d Sess. 135 (1984) (1982 United States Chamber of Commerce survey showing that $99 \%$ of the companies surveyed offered health or death benefits, $83 \%$ offered pension plans, and $50 \%$ offered long-term disability or salary continuation).

15s One possible explanation might be that formulating an integrated benefit scheme involves concessions and trade-offs that create a barrier to age discrimination. If this were the rationale for the different treatment of integrated benefits, one inquiry by a reviewing court should be the extent to which the negotiation of the benefit scheme involved good faith bargaining by both sides. Presumably, good faith bargaining would militate against interpreting a discriminatory provision as discriminatory "because of age."

186725 F.2d 211 (3d Cir. 1983), cert. denied, 469 U.S. 820 (1984).

187724 F.2d 1390 (9th Cir. 1984). Westinghouse Electric Corporation's integration claim in the appeal of EEOC v. Westinghouse Elec. Corp., 632 F. Supp. 343 (E.D. Pa. 1986), appeal pending, No. 86-1226 (3d Cir.) ("Westinghouse II"), relies on several of the proposed factors. See Brief of Appellant at 19-20, Westinghouse II:

That the Westinghouse plans are integrated is clear not only from the words of these plans, but also from their contemporaneous evolution. For over 25 years, Westinghouse and its unions have negotiated concurrently the terms and conditions under which employees become eligible to receive one immediate post-employment benefit-either immediate pension benefits or LIB - at the time of the termination; they have negotiated these benefits every three years within the context of one economic bargaining package . . . . These [factors, along with others,] point to one conclusion: that the Westinghouse plans do more than simply "interact"- they form a part of a comprehensive and integrated post-employment benefits program.

${ }^{168}$ Congress, in enacting a delay provision for the 1978 amendments to the ADEA, recognized the importance of trade-offs to collective bargaining. The amendments raised the maximum age covered by the statute to 70 and outlawed mandatory 
For example, the union may be willing to accept a lower amount of severance pay benefits in exchange for higher salaries or better health insurance. These decisions depend on the composition of the bargaining unit ${ }^{158}$ and its perception of the employer's financial health. If the prospect of a plant closing is strong, the unit may push for generous severance or LIB benefits. If the unit has a large number of young workers, it may be more interested in maternity or paternity leaves and family health insurance than in retirement or pension benefits. Whatever the outcome, the benefits generated by the collective bargaining process are interrelated because of the trade-offs that are inherent in the quid pro quo in bargaining. A plan generated outside the general collective bargaining agreement will not have as strong a claim of integration as one enacted concurrently with other terms of employment because in the former situation, meaningful trade-offs are difficult. ${ }^{100}$ The Westinghouse $I$ district court, in finding the pension plan and the LIB plans to be integrated, adverted to the importance of collective bargaining in assessing an integration claim, including the traditional deference given to these agreements. ${ }^{161}$

Another necessary consideration for evaluating claims of integration is the length of time the program has existed. The presence of collective bargaining cannot be determinative by itself of the existence of an integrated benefit arrangement because nominal bargaining actually may be thinly veiled unilateral action by the employer. An employer may announce a plant closing and shortly thereafter enter into what is nominally a collectively bargained severance pay agreement

retirement. Many existing contracts called for mandatory retirement at age 65 (the former maximum statutory age). Congress delayed the effective date of the amendments "to recognize, and provide the maximum deference to, [collectively bargained] contracts ... [because] these contracts were negotiated in good faith and . . . reciprocal agreements and concessions were made." S. REP. No. 493, 95th Cong., 1st Sess. 11 (1977), reprinted in 1978 U.S. Code Cong. \& Admin. News 504, 514.

${ }_{169}$ See King, The ADEA and Employee Benefit Plans-Part II, 56 N.Y. ST. B.J. 29,39 (1984) ("The extent to which a substantial percentage of the membership [of a collective bargaining unit] is . . . older or younger will influence how much of the total wage package will be allocated to improve retirement benefits.").

${ }_{160}$ See EEOC v. Great Atl. \& Pac. Tea Co., 618 F. Supp. 115, 122 (N.D. Ohio 1985) (Because severance and pension plans were adopted at different times and were documented separately, "the severance pay plan was not part and parcel of a total, integrated benefit package.").

161 EEOC v. Westinghouse Elec. Corp., 577 F. Supp. 1029, 1041 (D.N.J. 1982), rev'd, 725 F.2d 211 (3d Cir. 1983), cert. denied, 469 U.S. 820 (1984). The district court found the pension plan and the LIB plan to be "interlocked." Id. It emphasized that the LIB program was part of the pension and insurance agreement, "a collectively bargained agreement entered into ... a the same time as and collateral to the main collective bargaining agreement." Id. at 1039. It deserved the "deference due to such agreements in the interests of labor peace, the polestar of federal labor law." Id. at 1035. 
that excludes pension-eligible employees from receiving severance pay. ${ }^{162}$ Under these conditions, the employees, although given the opportunity to bargain, may have almost no bargaining power. ${ }^{163}$ Ineffective collective bargaining also can occur because of collusion between the labor organization and the employer. In that situation, there may be a cause of action against the labor organization under the $\mathrm{ADEA}^{104}$ and the National Labor Relations Act ("NLRA"). ${ }^{165}$ One court has suggested that when bargaining power is unfairly one-sided, the resulting plan is not "bona fide."

Borden's, in which two unions accepted identical severance agreements within a few months of the announced plant closing, presents a pointed example of a last-minute severance pay plan. In contrast, the Westinghouse I LIB program had been in the collective bargaining agreement for almost twenty years before the plant closings. ${ }^{167}$ Under those circumstances, it is difficult to characterize the LIB program as unilaterally imposed. A long-standing, collectively bargained program should raise a strong presumption of integration.

Specificity of the program is another important consideration. If an employer has a company-wide collective bargaining agreement, but certain programs apply only to specific facilities, integration of these programs could be considered absent. Again, Borden's and Westinghouse I provide a contrast. The LIB program applied to Westinghouse

103 After announcing a plant closing, an employer must engage in bargaining over the effects of the closing in "a meaningful manner . . . at a meaningful time." First Nat'l Maintenance Corp. v. NLRB, 452 U.S. 666, 681 (1981). One result of this "effects bargaining" may be a severance pay plan. For a comprehensive discussion of employer bargaining duties incident to a plant closing, see P. MiscimarRa, ThE NLRB and Managerial Discretion: Plant Closings, Relocations, SubcontractING, AND AUTOMATION 133-66 (1983).

${ }_{183}$ But see P. Miscimarra, supra note 162 , at $159-60$. One purpose of requiring effects bargaining incident to a plant closing is to ensure that bargaining takes place when the union's collective bargaining strength has not dissipated.

104 See 29 U.S.C. $\$$ 623(b) (1982) (labor organization prohibited from discriminating on the basis of age).

${ }_{165}$ Collusive bargaining may violate the union's duty of fair representation. See Steele v. Louisville \& N.R.R., 323 U.S. 192 (1944) (labor union cannot refuse to represent all in craft); see also Wallace Corp. v. NLRB, 323 U.S. 248, 255 (1944), reh'g denied, 324 U.S. 885 (1945) ("By its selection as bargaining representative, [the union] has become the agent of all the employees, charged with the responsibility of representing their interests fairly and impartially."); R. GORMAN, BAsIC TEXT ON LABOR LAw Unionization AND Collective BaRgaining 698-701 (1976) (A union's violation of the duty of fair representation may violate $\$ \S 8(\mathrm{~b})(1),(2),(3)$ of the NLRA.). 1985).

${ }^{168}$ EEOC v. Great Atl. \& Pac. Tea Co., 618 F. Supp. 115, 122 (N.D. Ohio

107 The LIB plan was added in 1960. Brief for Appellant at 5, EEOC v. Westinghouse Elec. Corp., 632 F. Supp. 343 (E.D. Pa. 1986), appeal pending, No. 861226 (3d Cir.) ("Westinghouse II"). The plant closing occurred in 1977. See Westinghouse I, 725 F.2d at 214. 
facilities nationwide. The Borden's severance pay program only applied to the specific facilities being closed.

A final criterion, considered relevant by the Seventh Circuit in its decision in EEOC v. Fox Point-Bayside School District, ${ }^{268}$ is the expectation of the prospective employee. The school district mandatorily retired a sixty-five-year-old teacher pursuant to the collective bargaining agreement. ${ }^{169}$ The retirement plan consisted of two components: the local collective bargaining agreement and the Wisconsin State Teachers Retirement System ("STRS"), a defined contribution plan providing retirement and disability benefits. ${ }^{170} \mathrm{~A}$ state statute established the STRS as the primary retirement plan but local collective agreements supplemented it. ${ }^{171}$ The disputed issue was whether the collective agreement and STRS merged into an integrated benefit plan.

The Seventh Gircuit held that the individual components joined to create a single retirement plan. ${ }^{172}$ The court said that the mandatory retirement provision of the collective agreement was "by its very nature central to a retirement plan. A prospective teacher considering offers of employment from two school districts certainly would not consider such a provision peripheral to an evaluation of the retirement plans offered by the two districts."178 The court distinguished Westinghouse I, Borden's, and Alford $v$. City of Lubbock ${ }^{174}$ on their facts, stating that those "cases do not hold that a mandatory retirement provision is separate from a retirement plan, and the reasoning [those cases] employ does not .help in analyzing that question."178

None of the proposed criteria independently should resolve the question of integration of benefit plans. This determination will depend on the facts of each case and the weight given to each criterion by the deciding court. Nevertheless, they provide a starting point for judicial evaluation of integration claims under section $4(f)(2)$. Applying them to Westinghouse I shows the LIB program to be integrated with the overall benefit arrangement because it was negotiated as part of the nationwide collective bargaining agreement and existed for many years prior to the plant closing. In Borden's, however, the severance pay plan

168772 F.2d 1294 (7th Cir. 1985).

109 See id. at 1298. The collective agreement called for mandatory retirement at age 65 . The delay provision of the 1978 ADEA amendments rendered them inapplicable. Id. at 1299.

${ }_{170}$ See id. at 1300 . The STRS was a contributory plan. See supra notes $122,125-$ 27 and accompanying text.

171772 F.2d at 1300 .

172 Id. at 1301 .

173 Id.

174664 F.2d 1263 (5th Cir.), cert. denied, 456 U.S. 975 (1982).

178 Id. at 1302. 
should not be afforded protection by section $4(f)(2)$ : the plan was negotiated independently from the other terms of the collective agreement, just prior to the plant closing and only applied to the plants being closed.

After a court determines that an integrated benefit scheme exists, it must test the integrated plan under the ADEA. The recent decision in EEOC v. Firestone Tire $\&$ Rubber Co. ${ }^{178}$ was the first case to find explicitly an integrated plan under section $4(f)(2)$ and to test that plan under the Act. ${ }^{177}$ Firestone, pursuant to its severance pay plan, did not pay benefits to employees eligible for retirement at the time of a plant closing. In the subsequent age discrimination suit, the court found that the severance pay was "part of a coordinated pension scheme" that was a bona fide pension plan within section $4(f)(2) .{ }^{178}$ Primary to this conclusion was the court's finding that the severance pay award was a minimum pension benefit, not a full lay-off benefit. ${ }^{179}$ The court also relied on the fact that the severance pay plan had been "part of [Firestone's] pension plan since 1955, ha[d] been included in the plant closure provision since 1976, ha[d] been bargained for and is contained in the same document" as is the pension plan. ${ }^{180}$ Having determined that an integrated pension plan existed, the court found that under this total plan older workers received "greater overall benefits than younger employees and that there was no adverse treatment."181 The integrated plan, therefore, did not violate section 4(a).

\section{ConcLusion}

With the growing concern for the cost of employee benefits, employers may increasingly attempt to provide fewer benefits for older workers. In addition, many collective bargaining agreements contain long-standing provisions denying severance or supplemental unemployment benefits to pension eligible employees ${ }^{\mathbf{1 8 2}}$ generally negotiated to maximize payments to individuals who are without other immediate sources of income. ${ }^{183}$ These situations are certain to lead to litigation under section $4(f)(2)$ of the ADEA, but it must be remembered that, in

176650 F. Supp. 1561 (W.D. Tenn. 1987).

127 Although Fox-Point found an integrated plan, the Seventh Circuit merely reversed the district court's grant of summary judgment. See 772 F.2d at 1303.

${ }^{178}$ Firestone, 650 F. Supp. at 1569.

179 Id. at 1567.

180 Id. at 1568.

181 Id. at 1569.

182 See, e.g., id. at 1563.

183 See Brief for Appellant at 7-10, EEOC v. Westinghouse Elec. Corp., 632 F. Supp. 343 (E.D. Pa. 1986) No. 86-1226 ("Westinghouse II"). 
the context of independent programs, section $4(f)(2)$ provides a narrow and specific protection.

The Westinghouse $I$ test provides results that conflict with the terms of the statute and with the legislative history. A careful examination of the statute and the regulations shows that the subterfuge clause, as interpreted in the regulations, limits the need for a vigorous test for "employee benefit plan." Adoption of the ERISA definitions would preclude the problems of Westinghouse I and would harmonize the definitions under ERISA and ADEA. The proposed interpretation of section $4(f)(2)$ adopts the regulations' objective test for determining whether an independent plan is a subterfuge and should reduce the amount of litigation over independent plans. The proposed test would also better enable employers and employees to estimate the possibility of successful litigation and to make appropriate decisions about settlement.

The issue of integrated benefit plans remains unsettled. The presence of effective collective bargaining, the length of existence of the program, the specificity of the program, and the impressions of a prospective employee are all relevant considerations in assessing a claim of integration. Section $4(f)(2)$ is certain to be a battleground for future cases. This Comment proposes an easily applied test for independent "employee benefit plans" under section $4(f)(2)$ that avoids the problems of the current interpretations and suggests a starting point for evaluating whether an integrated benefit scheme exists. 
